\title{
Mutational profiling of kinases in glioblastoma
}

Fonnet E Bleeker ${ }^{1,2,3^{*}}$, Simona Lamba', Carlo Zanon ${ }^{1,4}$, Remco J Molenaar ${ }^{5}$, Theo JM Hulsebos ${ }^{6}$, Dirk Troost ${ }^{7}$, Angela A van Tilborg ${ }^{7,8}$, W Peter Vandertop ${ }^{2,9}$, Sieger Leenstra ${ }^{10,11}$, Cornelis JF van Noorden ${ }^{5}$ and Alberto Bardelli ${ }^{1,12^{*}}$

\begin{abstract}
Background: Glioblastoma is a highly malignant brain tumor for which no cure is available. To identify new therapeutic targets, we performed a mutation analysis of kinase genes in glioblastoma.

Methods: Database mining and a literature search identified 76 kinases that have been found to be mutated at least twice in multiple cancer types before. Among those we selected 34 kinase genes for mutation analysis. We also included IDH1, IDH2, PTEN, TP53 and NRAS, genes that are known to be mutated at considerable frequencies in glioblastoma. In total, 174 exons of 39 genes in 113 glioblastoma samples from 109 patients and 16 high-grade glioma (HGG) cell lines were sequenced.

Results: Our mutation analysis led to the identification of 148 non-synonymous somatic mutations, of which 25 have not been reported before in glioblastoma. Somatic mutations were found in TP53, PTEN, IDH1, PIK3CA, EGFR, BRAF, EPHA3, NRAS, TGFBR2, FLT3 and RPS6KC1. Mapping the mutated genes into known signaling pathways revealed that the large majority of them plays a central role in the PI3K-AKT pathway.

Conclusions: The knowledge that at least 50\% of glioblastoma tumors display mutational activation of the PI3K-AKT pathway should offer new opportunities for the rational development of therapeutic approaches for glioblastomas. However, due to the development of resistance mechanisms, kinase inhibition studies targeting the PI3K-AKT pathway for relapsing glioblastoma have mostly failed thus far. Other therapies should be investigated, targeting early events in gliomagenesis that involve both kinases and non-kinases.
\end{abstract}

Keywords: Glioblastoma, Kinase, Gene, Molecular, Mutation, PI3K-AKT

\section{Background}

Cancer is a multi-step polygenic disease, caused by accumulation of genetic alterations in oncogenes and/or tumor suppressor genes resulting in neoplastic transformation. After the first transforming somatic mutation was found in the HRAS gene in human bladder cancer [1], transforming somatic mutations have been identified in numerous genes and in various types of malignant tumors. In the last decade, sequencing of the human genome and development of high-throughput technologies have enabled the systematic analysis of cancer genomes [2-11]. Genes encoding for kinases were found to be overrepresented in the group of cancer genes that have been found to be mutated [12]. Moreover, kinases represent effective therapeutic targets in

\footnotetext{
* Correspondence: f.e.bleeker@amc.uva.nl; alberto.bardelli@unito.it ${ }^{1}$ Department of Oncology, University of Torino, SP 142, Km 3.95, 10060 Candiolo, Torino, Italy; Candiolo Cancer Institute - FPO, IRCCS, Candiolo, Torino, Italy

Full list of author information is available at the end of the article
}

various types of cancer [13-19]. The description of 518 protein kinases constituting the 'kinome' [20] enabled systematic mutation analysis of kinases in colon cancer [2,6], and other types of cancer [4], including glioblastoma [5,21].

Glioblastoma is the most common malignant brain tumor and has a poor prognosis. Therapeutic advances have been made in the past decade with the addition of temozolomide chemotherapy to maximal safe tumor resection and radiotherapy. However, median survival is still limited to only 15 months in optimally treated patients $[22,23]$, and less than a year in the general population [24]. Therefore, novel therapies are urgently needed. For rational drug design, it is essential to unravel the underlying oncogenic mechanisms of glioblastoma. Different genes have been found to be involved in glioblastoma, by changes in expression, methylation, copy number alterations or mutations. A number of kinases has been known to be involved in glioblastoma by various mechanisms. 
A well-characterized mutation affects the protein kinase $E G F R$ and codes for a truncated constitutively activated form which is known as EGFRvIII. In addition, amplification and overexpression of EGFR are important in glioblastoma [25]. MET amplification [26], PIK3CA mutations and amplification $[7,10,11,26], E R B B 2$ mutations $[10,11]$ and amplification of CDK4 [11] and CDK6 [10,11,26,27] have been implicated in glioblastoma. Other kinases are found to be overexpressed in glioblastoma [28], including the kinase WEE1 [29]. The question is whether other kinases play a role as well by mutational activation in glioblastoma. We performed a mutation analysis including 34 kinase genes in 113 glioblastoma tumors and 16 highgrade glioma (HGG) cell lines.

\section{Methods}

\section{Selection of genes}

A search strategy was performed by database mining for kinase mutations in cancer in 2006. This search included the OMIM (Online Mendelian Inheritance in Man) of human genes and genetic disorders [30] and COSMIC (Catalogue of Somatic Mutations in Cancer) [31] databases. In addition, a literature search was performed using the key words 'kinase" and 'mutation"' in Pubmed. In silico, 217 kinases were identified to be mutated in cancer and 76 have been reported to contain non-synonymous somatic mutations in at least two independent tumor samples in the literature. We selected 34 of these $76 \mathrm{ki}$ nases for mutation analysis. Reasons for selecting these kinase genes were 1) they are known to be involved in pathways that play a role in the development of glioblastoma, 2) many mutations in these kinase genes have been reported in other cancer types and/or 3) there are smallmolecule drugs available for that kinase target (Table 1). In addition, we included IDH1, IDH2, NRAS, PTEN and TP53, genes known to be (relatively) frequently mutated in glioblastoma [11]. Specifically, we examined 174 exons in which mutations have been previously described for the following genes: AKT2, ATM, ATR, BRAF, BRD2, DDR1, DYRK2, EGFR, EPHA3, EPHA5, EPHA6, EPHB2, ERBB2, ERBB4, FGFR1, FGFR2, FGFR3, FGFR4, FLT1, FLT3, FRAP1, IDH1, IDH2, KDR, KIT, MAP2K4, MET, NRAS, NTRK2, NTRK3, PAK4, PDGFRA, PDPK1, PIK3CA, PTEN, RPS6KC1, STK11, TGFBR2 and TP53. In addition, the complete coding sequence of $A K T 1$ was sequenced in this tumor set, and mutations were not found, as described previously [32]. Furthermore, the molecular and survival analysis of $I D H 1$ and $I D H 2$ were published previously $[33,34]$.

\section{Patients, tumor samples and DNA extraction}

One hundred and thirteen fresh frozen glioblastoma samples were obtained from 109 patients from the tumor bank maintained by the Departments of Neurosurgery and Neuropathology at the Academic Medical Center (Amsterdam, The Netherlands). All patients were adults except one (age: 15 years). Both primary and secondary glioblastoma were included in this analysis. Research was performed on "waste" material and stored in a coded fashion. Consent for this project was reviewed and waivered by the Medical Ethics Review Committee of the Academic Medical Center and University of Amsterdam (reference number W14_224 \# 14.17.0286). Consent for removal of the tissue and its storage in the tumor bank for research purposes was obtained and documented in the patient's medical chart. Tumor samples were included only if at least $80 \%$ of the sample consisted of cancer cells, as verified by $H \& E$ staining. For all tumor samples matched germline DNA from blood samples was available. Matches between germline and tumor DNA were verified for all samples by direct sequencing of 26 single nucleotide polymorphisms (SNPs) at 24 loci (data not shown).

In addition, 16 high-grade glioma cell lines were included: the cell lines CCF-STTG1, Hs683, U87MG, U118MG, U251MG, U373MG, T98G (ATCC, Middlesex, United Kingdom), GAMG (Deutsche Sammlung von Mikroorganismen und Zellkulturen, Braunschweig, Germany), SKMG-3 (a gift of Dr C.Y. Thomas, University of Virginia Division of Hematology/Oncology, Charlottesville, VA), D384MG, SF763 (gifts of Dr M.L. Lamfers, Department of Neurosurgery, VU University, Amsterdam, The Netherlands), SF126 (a gift of Dr C. Van Bree, Department of Radiotherapy, Academic Medical Center) and the xenograft cell line IGRG121 (a gift of Dr B. Geoerger, Institut Gustave Roussy, Villejuif, France). A58, A60 and Gli-6 cell lines were derived from our own laboratory [35,36]. Genomic DNA was isolated as previously described [21].

\section{PCR and sequencing details}

Polymerase chain reaction (PCR) and sequencing primers were designed using Primer 3 and synthesized by InvitrogenTM (Life Technologies, Paisley, UK). PCR primers were designed to amplify the selected 174 exons and the flanking intron sequences, including splicing donor and acceptor regions of the genes (Additional file 1: Table S1). PCR products were approximately $400 \mathrm{bp}$ in length with multiple overlapping amplimers for larger exons. On each sample, 185 PCRs were performed in 384- and 96-well formats in 5 or $10 \mu \mathrm{l}$ reaction volumes, respectively. PCR conditions have been published previously [21]. Mutation Surveyor (Softgenetics, State College, PA, USA) was used to analyzed the sequencing data. Over 5,000 nucleotide changes were identified during this initial screening. Changes previously described as SNPs were excluded from further analyses. To ensure that the observed mutations were not PCR or sequencing artifacts, amplicons including non-silent mutations were independently re-amplified and re-sequenced in the corresponding tumors. All verified changes were re- 
Table 1 An overview of the 152 somatic mutations identified in 113 human glioblastoma samples and 16 high-grade glioma cell lines

\begin{tabular}{|c|c|c|c|c|c|c|}
\hline GBM sample \# & IDH1 & PTEN & TP53 & PIK3CA & EGFR & Other mutated genes \\
\hline $1 \mathrm{~T}$ & $\mathrm{R} 132 \mathrm{H}$ & & I162F & H1047Rt (CH5132799) & & \\
\hline $2 \mathrm{~T}$ & & & R248W & & & \\
\hline $4 \mathrm{~T}$ & & IVS5-1G > A & & & & \\
\hline $6 \mathrm{~T}$ & & & & & IVS21-5C > A & \\
\hline $8 \mathrm{~T}$ & & Y155C & $E 68 f f^{*} 54$ & & & \\
\hline $9 \mathrm{~T}$ & $\mathrm{R} 132 \mathrm{H}$ & & V122fs*25, R280G & delE110 & & \\
\hline $13 \mathrm{~T}$ & & & & F83S & & \\
\hline $14 \mathrm{~T}$ & & & C135Y, C238Y & E545A† (CH5132799) & & \\
\hline $16 \mathrm{~T}^{*}$ & $\mathrm{R} 132 \mathrm{H}$ & & I162F & H1047R & & \\
\hline $18 \mathrm{~T}$ & $\mathrm{R} 132 \mathrm{C}$ & & Y220C, G245S & & & \\
\hline $20 \mathrm{~T}$ & & & $C 275 Y$ & & & \\
\hline $21 \mathrm{~T}$ & & T319fs*2 & R248Q & & & \\
\hline $24 \mathrm{~T}$ & & K13E & & & & \\
\hline $26 \mathrm{~T}$ & & & & MIV & & \\
\hline $27 \mathrm{~T}$ & & & & R88Q & & \\
\hline $28 \mathrm{~T}$ & $\mathrm{R} 132 \mathrm{H}$ & & R273C & & & \\
\hline $29 \mathrm{~T}$ & & & $T 125 R$ & & & \\
\hline $30 \mathrm{~T}$ & & & & E545K† (CH5132799) & & \\
\hline $34 \mathrm{~T}$ & $\mathrm{R} 132 \mathrm{H}$ & & $P 64 f * 58$ & & & \\
\hline $35 \mathrm{~T}$ & & & R213W & & & \\
\hline $37 \mathrm{~T}$ & & R47K & E180K, Y220C & & & \\
\hline $38 \mathrm{~T}$ & $\mathrm{R} 132 \mathrm{H}$ & & & & & \\
\hline $43 \mathrm{~T}$ & & & & & & BRAF(V600E)† (sorafenib, vemurafenib) \\
\hline $45 \mathrm{~T}$ & & G132D & & & & \\
\hline $46 \mathrm{~T}$ & & & S106R, D208Y & & & \\
\hline $47 \mathrm{~T}$ & & Y46* & R273C & & & \\
\hline $49 \mathrm{~T}$ & & & IVS $8+1 G>T$ & & & \\
\hline $50 \mathrm{~T}$ & & L112P & & & & \\
\hline $51 \mathrm{~T}$ & & & & H1047L† (CH5132799) & & \\
\hline $53 \mathrm{~T}$ & & IVS3 + 1delGT & & & & NRAS(Q61L)† (MEK162) \\
\hline $55 \mathrm{~T}$ & & $\mathrm{R} 130^{*}$ & C176* & & & \\
\hline $56 \mathrm{~T}$ & & Q149* & F134L & & & \\
\hline
\end{tabular}


Table 1 An overview of the 152 somatic mutations identified in 113 human glioblastoma samples and 16 high-grade glioma cell lines (Continued)

\begin{tabular}{|c|c|c|c|c|c|c|}
\hline $58 \mathrm{~T}$ & & D24G & & & & \\
\hline $59 \mathrm{~T}$ & & & R273C & & & \\
\hline $61 \mathrm{~T}$ & & & S260fs*3 & & & \\
\hline $62 \mathrm{~T}$ & $\mathrm{R} 132 \mathrm{H}$ & & E286G, R306* & & & \\
\hline $64 \mathrm{~T}$ & & & P152S & & & \\
\hline $65 \mathrm{~T}$ & $\mathrm{R} 132 \mathrm{H}$ & & N13del & G118D & & \\
\hline $66 \mathrm{~T}$ & R132G & & R248W & & & \\
\hline $68 \mathrm{~T}$ & & & R273C & & & $B R A F(K 601 \mathrm{E}) \dagger$ (sorafenib, vemurafenib) \\
\hline $69 \mathrm{~T}$ & & & $\mathrm{R} 175 \mathrm{H}$ & & & \\
\hline $70 \mathrm{~T}$ & & S305fs*6 & & & & \\
\hline $71 \mathrm{~T}$ & & K125E & & & & \\
\hline $73 \mathrm{~T}$ & $\mathrm{R} 132 \mathrm{H}$ & & $\mathrm{R} 273 \mathrm{H}$ & & & \\
\hline $74 \mathrm{~T}$ & $\mathrm{R} 132 \mathrm{H}$ & & & & & \\
\hline $75 \mathrm{~T}$ & & Y46H & P152L & & & \\
\hline $76 \mathrm{~T}$ & & & & & E866D+ (lapatinib, vandetanib, AEE788) & \\
\hline $78 \mathrm{~T}$ & & & $\mathrm{H} 179 \mathrm{D}$ & & & \\
\hline $79 \mathrm{~T}$ & $\mathrm{R} 132 \mathrm{H}$ & & & & & \\
\hline $81 \mathrm{~T}$ & $\mathrm{R} 132 \mathrm{H}$ & & V157F, R282W & C420R & & \\
\hline $83 \mathrm{~T}$ & & & & & & BRAF(V600E) \\
\hline $84 \mathrm{~T}$ & R132L & & Y236N & & & \\
\hline $87 \mathrm{~T}$ & & G127R & $\mathrm{R} 158 \mathrm{H}$ & & & FLT3(A627T)† (crenolanib, midostaurin) \\
\hline $88 \mathrm{~T}$ & & $P 248 f s^{*} 5$ & & & & \\
\hline $89 \mathrm{~T}$ & & I253insSTOP & & & & \\
\hline $92 \mathrm{~T}$ & & & & & L210Q (cetuximab, panitumumab) & \\
\hline $93 \mathrm{~T}$ & & & R282W & H1047Y+ (CH5132799) & & \\
\hline $96 \mathrm{~T}$ & $\mathrm{R} 132 \mathrm{H}$ & & K120E & & & \\
\hline $97 \mathrm{~T}$ & & & R248W & & & \\
\hline $98 \mathrm{~T}$ & & IVS8-1G > A & R213* & & & \\
\hline $99 \mathrm{~T}$ & & $\mathrm{R} 242^{*}$ & Y220C & & P589L† (cetuximab, panitumumab) & \\
\hline $101 \mathrm{~T}$ & & $\operatorname{IVS} 3+1 \mathrm{G}>\mathrm{T}$ & & & & \\
\hline $102 \mathrm{~T}$ & & & & & A597P+ (cetuximab, panitumumab) & \\
\hline $104 \mathrm{~T}$ & & Y336* & & & & \\
\hline
\end{tabular}


Table 1 An overview of the 152 somatic mutations identified in 113 human glioblastoma samples and 16 high-grade glioma cell lines (Continued)

\begin{tabular}{|c|c|c|c|c|c|c|}
\hline $105 \mathrm{~T}$ & & IVS4-1G>C & & & & \\
\hline $106 T^{*}$ & & IVS4-1G >C & & & & \\
\hline $107 \mathrm{~T}$ & & $\mathrm{R} 130^{*}$ & & & G598V† (cetuximab, panitumumab) & \\
\hline $108 \mathrm{~T}^{*}$ & & $\mathrm{R} 130^{*}$ & & & G598V & \\
\hline $109 \mathrm{~T}$ & & & $\mathrm{R} 175 \mathrm{H}$ & & & \\
\hline $111 \mathrm{~T}$ & & & & MIV & & \\
\hline $112 \mathrm{~T}$ & $\mathrm{R} 132 \mathrm{H}$ & & $\mathrm{R} 175 \mathrm{H}$ & & & \\
\hline $113 \mathrm{~T}$ & $\mathrm{R} 132 \mathrm{H}$ & & $\mathrm{H} 168 \mathrm{R}$ & & & \\
\hline $114 \mathrm{~T}$ & & 12535 & & & & \\
\hline $115 T^{*}$ & $\mathrm{R} 132 \mathrm{H}$ & & $\mathrm{H} 168 \mathrm{R}$ & & & \\
\hline $117 \mathrm{~T}$ & & P96L & & & & TGFBR2(A204D) (LY2157299, LY2424087, TR1) \\
\hline $118 \mathrm{~T}$ & $\mathrm{R} 132 \mathrm{H}$ & & M2371 & & & \\
\hline \multicolumn{7}{|l|}{ Cell lines } \\
\hline Gli6 & & R130L & $E 336^{*}$ & & & \\
\hline SKMG3 & & & $\mathrm{R} 282 \mathrm{~W}$ & & & \\
\hline T98G & & $L 42 R$ & M237l & & & \\
\hline U118 & & IVS8 $+1 G>T$ & $\mathrm{R} 213 \mathrm{Q}$ & & & \\
\hline U251MG & & $\mathrm{E} 242 \mathrm{fs}^{*} 15$ & $\mathrm{R} 273 \mathrm{H}$ & & & \\
\hline U373MG & & $\mathrm{E} 242 \mathrm{fs}^{*} 15$ & $\mathrm{R} 273 \mathrm{H}$ & & & \\
\hline U87 & & $\mathrm{IVS} 3+1 \mathrm{G}>\mathrm{T}$ & & & & EPHA3(K500N) (KB004), RPS6KC1(Q741*) \\
\hline SF126 & & G129R & & & & \\
\hline SF-763 & & & R158L & & & \\
\hline A58 & & T319fs*2 & $\mathrm{R} 248 \mathrm{Q}$ & & & \\
\hline A60 & & $\mathrm{K} 13 \mathrm{E}$ & & & & \\
\hline CCF-STTG1 & & L112R & & & & \\
\hline D384 & & & A159V & & & \\
\hline GAMG & & & L265P & & & \\
\hline Hs683 & & & $\mathrm{R} 248 \mathrm{Q}$ & & & \\
\hline IGRG-121 & & Y225* & & & & \\
\hline
\end{tabular}

37 samples without mutation in sequenced genes are excluded from this table. Mutations depicted in bold are, to our knowledge, novel in cancer, mutations in italics have been reported in cancer but are novel in glioblastoma.

*indicates recurrent tumor ( $16 \mathrm{~T}$ is recurrent glioblastoma of $1 \mathrm{~T}$, $106 \mathrm{~T}$ is recurrent glioblastoma of $105 \mathrm{~T}$, $108 \mathrm{~T}$ is recurrent glioblastoma of $107 \mathrm{~T}$, $115 \mathrm{~T}$ is recurrent glioblastoma of $2 \mathrm{~T}$ ). + denotes a (likely) activating mutation. Known kinase inhibitors for that specific target or kinase region are shown between brackets (only shown at first occurence in table). 
sequenced in parallel with the matched normal DNA from blood samples to distinguish between somatic mutations and SNPs not previously described.

In the present study, a total of 23,865 PCR products, covering 9.5 Mb of tumor genomic DNA, were generated and subjected to direct Sanger sequencing. Over 5,000 nucleotide changes were identified during this initial screening. Changes previously described as SNPs, synonymous changes and intronic changes not predicted to affect splicing were excluded from further analyses. To ensure that the remaining mutations were not PCR or sequencing artefacts, amplicons were independently re-amplified and resequenced in the corresponding tumors. All confirmed changes were resequenced in parallel with the matched normal DNA to distinguish between somatic mutations and SNPs not previously described. We used the COSMIC database to investigate whether mutations found were novel in cancer or glioblastoma.

\section{Cloning}

For cloning of the PCR products the $\mathrm{pcDNA}^{\mathrm{rm}} 3.3-\mathrm{TOPO}^{\circ}$ TA Cloning Kit (Invitrogen) was used according to the manufacturer's guidelines. The TOPO ligation reaction (containing $2 \mu \mathrm{l}$ of fresh PCR product and $1 \mu \mathrm{l}$ TOPO vector) was performed for $5 \mathrm{~min}$ at room temp. Competent E. coli were transformed with the TOPO cloning reaction and spread on a pre-warmed selective plate (ampicillin). Plates were incubated at $37^{\circ} \mathrm{C}$ overnight. White colonies were picked for PCR analysis and sequencing, using the protocol described above.

\section{Results and discussion}

Clinical and histological characteristics of 109 glioblastoma patients from which 113 tumor samples were extracted are shown in Table 2. An overview of the 148 somatic mutations that we identified in these 113 human glioblastoma samples and 16 high-grade glioma cell lines is shown in Table 1. Somatic mutations were found in TP53 (61 mutations), PTEN (39), IDH1 (20), PIK3CA (13), EGFR (7), BRAF (3), EPHA3 (1), NRAS (1), TGFRB2 (1), FLT3 (1) and RPS6KC1 (1). To our knowledge twenty-five of these have not been described before in glioblastoma and are highlighted in Table 1.

\section{Overall}

The observed mutation rate of all non-synonymous somatic mutations (13.2 mutations/Mb) was higher than the expected 'passenger' mutation rate $\left(P<1 \times 10^{-15}\right.$, binomial distribution) [37], indicating that most of these mutations probably represent 'driver' mutations. In the sequenced genes, 76 out of 113 (67\%) glioblastoma tumors displayed at least one somatic mutation; no mutation was identified in 37 glioblastoma samples. In all cell lines at least one mutation in TP53 or PTEN was found. The maximum
Table 2 Baseline characteristics of 113 glioblastoma patients. Data are mean (range), number (\%) or median (95\% Cl)

\begin{tabular}{lll}
\hline Characteristic & Specification & Outcome \\
\hline Age & Mean (range), in years & $54(15-81)$ \\
Irradiation dosage & Mean (range), Gy & $39(0-88)$ \\
KPS & Mean (range), in points & $76(50-90)$ \\
Gender & Male & $61(56 \%)$ \\
& Female & $48(44 \%)$ \\
Surgical procedure & Gross total removal & $62(57 \%)$ \\
& Biopsy or irradical resection & $57(43 \%)$ \\
Tumor occurrence & Primary glioblastoma & $94(86 \%)$ \\
& Secondary glioblastoma & $15(14 \%)$ \\
& Recurrent tumor & $8(7 \%)$ \\
Overall survival* & Median (95\% Cl), in days & $252(206-318)$ \\
Progression free survival* & Median (95\% Cl), in days & $131(105-157)$ \\
\hline $\begin{array}{l}\text { Data are mean (range), number (\%) or median (95\% Cl) *Survival data was } \\
\text { available for 98 glioblastoma patients. } \\
\text { Abbreviations: Gy, Gray; KPS, Karnofsky Performance Status. }\end{array}$ &
\end{tabular}

number of mutations in a single sample observed was three, occurring in both tumor and cell line samples. Only non-silent mutations were further investigated to determine whether they were somatic or not. Differences in non-silent mutation rate between untreated samples and recurrent samples treated prior with temozolomide chemotherapy were not found. Therefore, it is impossible to conclude whether samples derived from patients that had been pretreated with temozolomide $(n=8)$ developed a hypermutator phenotype, as was described for other glioblastoma samples after temozolomide treatment [5]. Remarkably, no additional mutations were observed in the four recurrent tumors compared to their primary glioblastomas, which were both included in the mutation analysis.

Some of the mutations were probably present in a small fraction of cancer cells [38,39]. Cloning of the PCR product helped to confirm the mutation in all tested samples. An example is shown in Figure 1. For some amplicons, the PCR reaction failed twice, as occurred for example for exon 4 of PTEN in the SKMG-3 cell line. This cell line is known for a deletion containing exon 4 [40]. Hence, in this case, the incapacity of amplification is probably caused by the deletion.

\section{Mutation prevalences of genes}

For PIK3CA and PTEN the mutation frequencies are not different from previous reports [41-43]. The mutation frequencies of TP53 (46\%) and IDH1 (17\%) are higher than previously reported in glioblastoma samples $[10,41,42,44]$. Fourteen \% of the samples were from secondary glioblastoma, which is also higher than in the aforementioned studies. Since TP53 and IDH1 mutations occur mostly in secondary glioblastoma, the relatively high number of 


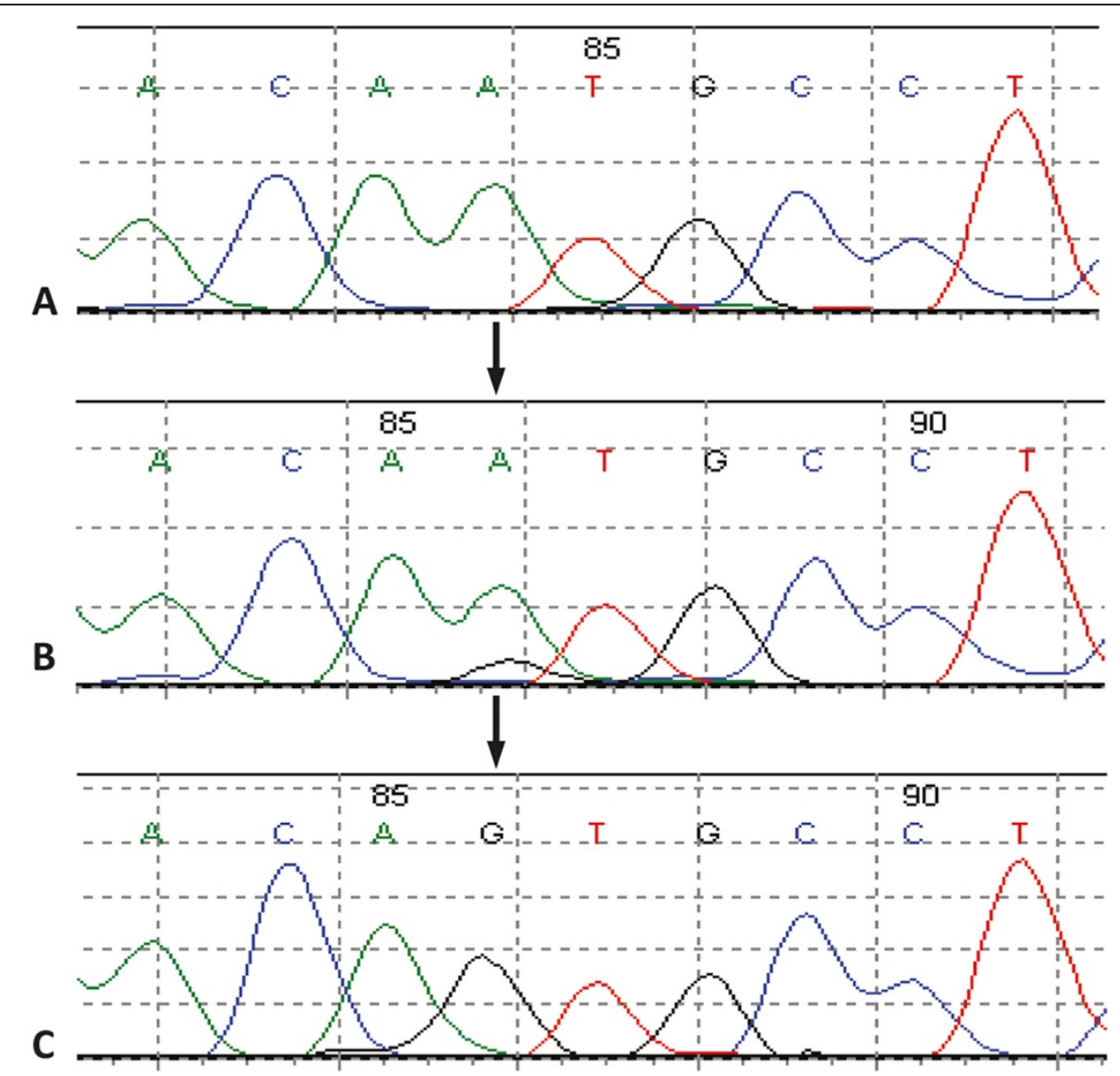

Figure 1 Somatic mutation confirmed by cloning. A, chromatogram of matched normal blood sample; B, chromatogram of tumor sample; C, chromatogram of cloned PCR product. Arrows indicate the location of missense somatic mutations. Numbers above the sequences are part of the software output. PIK3CA, c.158A>G, p.M2V.Mutation prevalence of genes.

secondary glioblastoma can explain the relatively high number of TP53 and IDH1 mutations. Regarding TP53, we identified seven samples with two mutations in TP53. When corrected for mutated single samples, the mutation percentage is $39 \%$, still slightly higher than reported. Mutation details for $I D H 1$ have been published separately [34,45]. In EGFR, the mutation frequency is lower than reported previously, due to the fact that we sequenced only exons belonging to the kinase domain, whereas Lee et al. found mutations predominantly in the extracellular domain $[37,46]$. No $A K T 1$ mutations were found, as described previously [32].

A new mutation hotspot, providing a novel therapeutic target in a significant percentage of glioblastoma patients, was not identified in the sequenced kinase genes. This may be due to the limited number of kinases which was sequenced in this project. However, other genome-wide glioblastoma sequencing projects have not resulted in the discovery of novel mutation hotspots in kinases either $[10,11,47]$. This supports the theory that every cancer type may have its own mutated cancer candidate genes, and only a few of these genes are shared by different cancer types [48]. Furthermore, the mutations themselves, rather than the genes, may be cancer-specific $[9,10,44,45]$. Therefore, we cannot exclude that other exons of the genes may exhibit a more frequently mutated genotype. Notably, glioblastomas exhibit a different mutation profile for some genes as compared to other tumor types. For example, most EGFR and ERBB2 mutations in lung cancer are found in the kinase domain $[49,50]$, and that is why we included those regions in our study. However, recent studies show that these genes are predominantly mutated in the extracellular domain in glioblastoma $[10,46]$. Some of the novel mutations that we have found affect kinases, for example EPHA3, recently demonstrated as a functional targetable receptor in glioblastoma [51]. These are clearly amenable to pharmacologic intervention and represent potential novel therapeutic targets for glioblastoma.

\section{Cell lines}

Neither IDH1 nor PIK3CA mutations were found in any of the cell lines examined. Compared to the mutation 
frequency (17\% and 11\%) that we found in 109 glioblastoma samples, the lack of IDH1 and PIK3CA mutations in our panel of 16 HGG cell lines is remarkable. However, currently available glioblastoma cells lines do not have endogenous $I D H 1 / 2$ mutations. Thus far, three anaplastic glioma cell lines have been reported to have $I D H 1 / 2$ mutations [52-55]. However, the fact that there were no mutations in the 16 established cell lines is not surprising, because most lines are derived from glioblastomas and most of these were probably primary glioblastoma, in which $I D H 1 / 2$ mutations are rare $[6,44,45]$. On the other hand, glioblastoma cell lines with PIK3CA mutations have been described [43].

Two cell lines generated from glioblastoma samples included in our mutational screen were also subjected to the mutation analysis we performed. Of note, both one TP53 (R248Q) and two PTEN mutations (T319fs*2 and $\mathrm{K} 13 \mathrm{E})$ in the cell lines were found in homozygosity, whereas the same mutations in the corresponding original tumor were heterozygous. We included tumor samples only if at least $80 \%$ of the sample consisted of cancer cells, as verified by $H \& E$ staining. Therefore, we considered the chance of contamination by normal brain tissue to be small. As established cell lines derived from glioblastoma resemble the original tumors in patients poorly when compared at the level of DNA alterations $[35,56]$, we argue that one allele of the gene may have been lost during the establishment of the cell lines or during cell culture afterward.

One of the changes that was identified in EPHA3 $(\mathrm{K} 500 \mathrm{~N})$, was previously reported by us [57], to occur in the cell line U87MG, for which no matched normal tissue is available. Therefore, the somatic status of this mutation could not be ascertained. As the U87MG cell line is widely used in basic glioblastoma research, our results suggest that U87MG may not be a viable model for all research proposes due to the EPHA3 mutation.

\section{PIK3CA, PTEN in the PI3K-AKT pathway}

Somatic mutations in PIK3CA have been found in various tumor types, affecting particularly exons 9 and 20 and to a lesser extent exon 1. In our glioblastoma samples, twelve mutations were found in PIK3CA, five were located in exon 1, two in exon 9 and three in exon 20. One of the five mutations in exon 1 has not been reported before in cancer.

PIK3CA and PTEN mutations were found mutually exclusive in our glioblastoma samples, as was previously observed in glioblastoma [58,59], and other tumor lineages $[60,61]$. This suggests that the mutations exert overlapping cellular functions. Indeed, both the lipid kinase PI3K and the phosphatase PTEN act as central regulators of the PI3K-AKT pathway by controlling the cellular levels of phosphatidylinositol-3-phosphate. Activating mutations in the PIK3CA oncogene result in increased PI3K catalytic activity and constitutive downstream signaling. In contrast, the tumor suppressor protein PTEN counteracts the effect of PI3K and acts as a negative regulator of PI3K signaling [62]. Consequently, inactivating mutations in PTEN also result in constitutive downstream signalling of the PI3K-AKT pathway.

In our limited analysis, we found most mutations in genes to belong to the PI3K-AKT pathway; mutational activation of this pathway was observed in at least $50 \%$ of glioblastomas, similar to findings in other studies $[48,63]$. Whole-genome sequencing efforts also studied nonkinase genes in this pathway (NF1) and thus revealed an even higher percentage ( 90\%) [11]. This indicates that the PI3K-AKT pathway represents an interesting therapeutic target for glioblastomas. However, the results of most clinical trials with (kinase) inhibitors interfering in this pathway have been disappointing thus far [25,64-66].

As many glioblastoma have an activating EGFR mutation $[10,11,46]$, the first clinical studies with EGFR inhibitors had high expectations [25]. However, the response to EGFR inhibitors was found to be limited to only 15-20\% of glioblastoma patients with activating EGFR mutations [42,67-69]. The partial response is likely caused by other molecular events downstream of EGFR, leading to simultaneous activation of downstream effectors. For example, the oncogenic PI3K-AKT signaling pathway is activated in $15 \%$ of glioblastoma via activating mutations in the PIK3CA oncogene [11] and in $36 \%$ of glioblastoma via mutationally or transcriptionally inactivated PTEN [11]. As a result, the limited response of therapeutic EGFR inhibition was thought to be neutralized by loss of PTEN. This explains the correlation observed between the response to EGFR inhibitors and the co-expression of EGFRvIII and PTEN proteins $[37,42,70]$ or phosphorylated AKT [71]. PTEN-deficient glioblastoma patients were expected to respond to a cocktail of drugs consisting of an EGFR inhibitor and rapamycin [70], but the results were not impressive either [72]. Rational drug design and rationally designed clinical trials to test these drugs are needed, because an almost infinite number of compounds is currently available, and these can be tested in limitless numbers of combinations. With genomics approaches, discoveries of common features of different types of tumors may lead to new therapeutic targets and drugs for other tumor types as well [28,73,74].

These findings indicate that single-agent kinase inhibition therapy is not sufficient to target the PI3K-AKT pathway successfully. Similar negative findings have been reported for single drug trials that target the ERK pathway in colon carcinoma [75], where mechanistic studies have shown that concomitant inhibition of other pathways, (i.e. PI3K-AKT) is more effective in these patients [76]. Analogous to such investigations, additional research efforts, 
such as ours, should pursue the discovery of other targetable molecular alterations in glioblastoma, in order to facilitate the development of multidrug trials that are less likely to fail due to resistance mechanisms. Other kinases were found to be important in glioblastoma as well and may provide therapeutic options. Inhibition of the kinase WEE1 has shown to sensitize glioblastoma to ionizing radiation in vivo [29,77]. Other single-agent kinase therapies targeting PDGFRA, MET and FGFR2/3 should be studied as well [47]. However, the question has been raised whether rational single-agent kinase inhibition treatment will suffice in the treatment of glioblastoma. Multiple pathways are altered in glioblastoma $[10,11,28]$ by (epi) genetic $[10,11]$, transcriptional [78-80] and metabolic mechanisms [10]. An important hallmark of glioblastoma is intratumoral heterogeneity [38]. Thousands of clonal mutations have been identified in glioblastomas, but, only some are common [38], showing that the cancer phenotype iscomplex. Each tumor, and also each glioblastoma, evolves as a result of stochastic and environmental processes in different mutations [39]. As tumor cells contain thousands of mutations, both 'driver' and 'passenger', that affect many pathways [81], it may be impossible to target these adequately [39]. Notably, the 'passenger' mutations, most of the alterations, may not provide growth advantage per se, but could cause resistance to therapy in a subset of cells, which can dominate the tumor next. We, and others [39], are convinced that the focus should be on targeting early common alterations in glioblastoma. For example, inaugural IDH1 mutations [28], causing metabolic alterations, may be an interesting therapeutic target $[52,82]$. As only a subset of glioblastoma has IDH1 mutations [45], for IDH1 wild-type tumors other, perhaps metabolic [83,84], therapies should be investigated.

\section{Conclusion}

In conclusion, molecular profiling of tumor genomes has provided a comprehensive list of cancer genes and of the signaling pathways they control. These efforts have, amongst others, led to the discovery that glioblastomas harbor thousands of mutations whereas only some common driver genes are involved. Extensive whole-genome sequencing of glioblastoma has been performed in recent years $[11,47]$, but it has been calculated that the discovery of molecular alterations in GBM is nowhere near saturation as of yet [85]. Whereas the present study did not reveal novel mutational hotspots in kinases in glioblastoma, we did observe a strong clustering of mutations in genes belonging to the PI3K-AKT pathway. This pathway is more frequently activated by genomic aberrations than any other signaling pathway in many tumor types. However, due to the development of resistance mechanisms, kinase inhibition studies targeting the PI3K-AKT pathway for relapsing glioblastoma have mostly failed thus far. Other therapies should be investigated on targeting both kinases and non-kinases that are involved in early events in gliomagenesis.

\section{Additional file}

Additional file 1: Table S1. Thirty-nine genes selected for mutation analysis and primer details to sequence the indicated 174 exons of the selected genes. Primer sequences are in $5^{\prime}$ to $3^{\prime}$ direction.

\section{Competing interests}

Alberto Bardelli is a shareholder of Horizon Discovery Limited.

\section{Authors' contributions}

FEB, SLa and CZ performed the experiments. TJMH, DT, and AAVT contributed samples. FEB, RJM and AB analyzed the data. FEB, WPV, SLe, CJFVN and $A B$ conceived and designed the study. FEB, RJM, SLe, CJFVN and $A B$ wrote the manuscript. All authors read and approved the final manuscript.

\section{Funding}

This work was supported by grants from ABC2 (AvT), European Community's Seventh Framework Programme under grant agreement no. 259015 COLTHERES (AB); Associazione Italiana per la Ricerca sul Cancro (AIRC) IG grant no. 12812 (AB); AIRC 2010 Special Program Molecular Clinical Oncology 5 per mille, project no. 9970 (AB); FPRC 5 per mille 2010 and 2011 Ministero della Salute $(A B)$; Ministero dell'Istruzione, dell'Università e della Ricerca, progetto PRIN (AB); Progetti di Ateneo-2011, Università di Torino

(ORTO11RKTW to AB). F.E. Bleeker was supported by a NWO travel grant and a Netherlands Genomic Initiative Fellowship. R.J. Molenaar was supported by an AMC PhD Scholarship.

\section{Author details}

'Department of Oncology, University of Torino, SP 142, Km 3.95, 10060 Candiolo, Torino, Italy; Candiolo Cancer Institute - FPO, IRCCS, Candiolo, Torino, Italy. ${ }^{2}$ Neurosurgical Center Amsterdam, Location Academic Medical Center, Meibergdreef 9, 1105 AZ, Amsterdam, The Netherlands. ${ }^{3}$ Department of Clinical Genetics, Academic Medical Center and University of Amsterdam, Meibergdreef 9, 1105 AZ, Amsterdam, The Netherlands. ${ }^{4}$ Neuroblastoma Laboratory, Pediatric Research Institute, Fondazione Città della Speranza, Corso Stati Uniti 4, 35127 Padua, Italy. ${ }^{5}$ Department of Cell Biology and Histology, Academic Medical Center, University of Amsterdam, Meibergdreef 9, 1105 AZ, Amsterdam, The Netherlands. 'Department of Neurogenetics, Academic Medical Center, University of Amsterdam, Meibergdreef 9, 1105 AZ, Amsterdam, The Netherlands. ${ }^{7}$ Department of Neuropathology, Academic Medical Center, University of Amsterdam, Meibergdreef 9, 1105 AZ, Amsterdam, The Netherlands. ${ }^{8}$ Department of Pathology, UMC St. Radboud, Geert Grooteplein-Zuid 10, 6525 GA, Nijmegen, The Netherlands. ${ }^{9}$ Neurosurgical Center Amsterdam, Location Vrije Universiteit Medical Center, De Boelelaan 1117, $1081 \mathrm{HZ}$, Amsterdam, The Netherlands. ${ }^{10}$ Department of Neurosurgery, St. Elisabeth Ziekenhuis, Hilvarenbeekse Weg 60, 5022 GC, Tilburg, The Netherlands. ${ }^{11}$ Department of Neurosurgery, Erasmus Medical Center, 's-Gravendijkwal 230, 3015 CE, Rotterdam, The Netherlands. ${ }^{12}$ FIRC Institute of Molecular Oncology, Via Adamello 16, 20139 Milan, Italy.

Received: 14 April 2014 Accepted: 17 September 2014

Published: 26 September 2014

\section{References}

1. Reddy EP, Reynolds RK, Santos E, Barbacid M: A point mutation is responsible for the acquisition of transforming properties by the T24 human bladder carcinoma oncogene. Nature 1982, 300(5888):149-152.

2. Bardelli A, Parsons DW, Silliman N, Ptak J, Szabo S, Saha S, Markowitz S, Willson JK, Parmigiani G, Kinzler KW, Vogelstein B, Velculescu VE: Mutational analysis of the tyrosine kinome in colorectal cancers. Science 2003, 300(5621):949.

3. Davies H, Hunter C, Smith R, Stephens P, Greenman C, Bignell G, Teague J, Butler A, Edkins S, Stevens C, Parker A, O'Meara S, Avis T, Barthorpe S, Brackenbury L, Buck G, Clements J, Cole J, Dicks E, Edwards K, Forbes S, Gorton M, Gray K, Halliday K, Harrison R, Hills K, Hinton J, Jones D, Kosmidou V, 
Laman $\mathrm{R}$, et al: Somatic mutations of the protein kinase gene family in human lung cancer. Cancer Res 2005, 65(17):7591-7595.

4. Greenman C, Stephens P, Smith R, Dalgliesh GL, Hunter C, Bignell G, Davies H, Teague J, Butler A, Stevens C, Edkins S, O'Meara S, Vastrik I, Schmidt EE, Avis T, Barthorpe S, Bhamra G, Buck G, Choudhury B, Clements J, Cole J, Dicks E, Forbes S, Gray K, Halliday K, Harrison R, Hills K, Hinton J, Jenkinson $A$, Jones $D$, et al: Patterns of somatic mutation in human cancer genomes. Nature 2007, 446(7132):153-158.

5. Hunter C, Smith R, Cahill DP, Stephens P, Stevens C, Teague J, Greenman C, Edkins S, Bignell G, Davies H, O'Meara S, Parker A, Avis T, Barthorpe S, Brackenbury L, Buck G, Butler A, Clements J, Cole J, Dicks E, Forbes S, Gorton M, Gray K, Halliday K, Harrison R, Hills K, Hinton J, Jenkinson A, Jones D, Kosmidou V, et al: A hypermutation phenotype and somatic MSH6 mutations in recurrent human malignant gliomas after alkylator chemotherapy. Cancer Res 2006, 66(8):3987-3991.

6. Parsons DW, Wang TL, Samuels Y, Bardelli A, Cummins JM, DeLong L, Silliman N, Ptak J, Szabo S, Willson JK, Markowitz S, Kinzler KW, Vogelstein B, Lengauer C, Velculescu VE: Colorectal cancer: mutations in a signalling pathway. Nature 2005, 436(7052):792.

7. Samuels Y, Wang Z, Bardelli A, Silliman N, Ptak J, Szabo S, Yan H, Gazdar A, Powell SM, Riggins GJ, Willson JK, Markowitz S, Kinzler KW, Vogelstein B, Velculescu VE: High frequency of mutations of the PIK3CA gene in human cancers. Science 2004, 304(5670):554.

8. Stephens P, Edkins S, Davies H, Greenman C, Cox C, Hunter C, Bignell G, Teague J, Smith R, Stevens C, O'Meara S, Parker A, Tarpey P, Avis T, Barthorpe A, Brackenbury L, Buck G, Butler A, Clements J, Cole J, Dicks E, Edwards K, Forbes S, Gorton M, Gray K, Halliday K, Harrison R, Hills K, Hinton $J$, Jones $D$, et al: A screen of the complete protein kinase gene family identifies diverse patterns of somatic mutations in human breast cancer. Nat Genet 2005, 37(6):590-592.

9. Mardis ER, Ding L, Dooling DJ, Larson DE, McLellan MD, Chen K, Koboldt DC, Fulton RS, Delehaunty KD, McGrath SD, Fulton LA, Locke DP, Magrini VJ, Abbott RM, Vickery TL, Reed JS, Robinson JS, Wylie T, Smith SM, Carmichael L, Eldred JM, Harris CC, Walker J, Peck JB, Du F, Dukes AF, Sanderson GE, Brummett AM, Clark E, McMichael J, et al: Recurring mutations found by sequencing an acute myeloid leukemia genome. N Engl J Med 2009, 361(11):1058-1066.

10. Parsons DW, Jones S, Zhang X, Lin JC, Leary RJ, Angenendt P, Mankoo P, Carter H, Siu IM, Gallia GL, Olivi A, McLendon R, Rasheed BA, Keir S, Nikolskaya T, Nikolsky Y, Busam DA, Tekleab H, Diaz LA Jr, Hartigan J, Smith DR, Strausberg RL, Marie SK, Shinjo SM, Yan H, Riggins GJ, Bigner DD, Karchin R, Papadopoulos N, Parmigiani G, et al: An integrated genomic analysis of human glioblastoma multiforme. Science 2008, 321(5897):1807-1812.

11. TCGAN: Comprehensive genomic characterization defines human glioblastoma genes and core pathways. Nature 2008, 455(7216):1061-1068.

12. Futreal PA, Coin L, Marshall M, Down T, Hubbard T, Wooster R, Rahman N, Stratton MR: A census of human cancer genes. Nat Rev Cancer 2004, 4(3):177-183.

13. Slamon DJ, Leyland-Jones B, Shak S, Fuchs H, Paton V, Bajamonde A, Fleming T, Eiermann W, Wolter J, Pegram M, Baselga J, Norton L: Use of chemotherapy plus a monoclonal antibody against HER2 for metastatic breast cancer that overexpresses HER2. N Engl J Med 2001, 344(11):783-792.

14. Verweij J, Casali PG, Zalcberg J, LeCesne A, Reichardt P, Blay JY, Issels R, van Oosterom A, Hogendoorn PC, Van Glabbeke M, Bertulli R, Judson I: Progression-free survival in gastrointestinal stromal tumours with high-dose imatinib: randomised trial. Lancet 2004, 364(9440):1127-1134.

15. Chapman PB, Hauschild A, Robert C, Haanen JB, Ascierto P, Larkin J, Dummer R, Garbe C, Testori A, Maio M, Hogg D, Lorigan P, Lebbe C, Jouary T, Schadendorf D, Ribas A, O'Day SJ, Sosman JA, Kirkwood JM, Eggermont AM, Dreno B, Nolop K, Li J, Nelson B, Hou J, Lee RJ, Flaherty KT, McArthur GA, BRIM-3 Study Group: Improved survival with vemurafenib in melanoma with BRAF V600E mutation. N Engl J Med 2011, 364(26):2507-2516.

16. Douillard JY, Oliner KS, Siena S, Tabernero J, Burkes R, Barugel M, Humblet $Y$, Bodoky G, Cunningham D, Jassem J, Rivera F, Kocákova I, Ruff P, BłasińskaMorawiec M, Šmakal M, Canon JL, Rother M, Williams R, Rong A, Wiezorek J, Sidhu R, Patterson SD: Panitumumab-FOLFOX4 treatment and RAS mutations in colorectal cancer. N Engl J Med 2013, 369(11):1023-1034.

17. Miller VA, Hirsh V, Cadranel J, Chen YM, Park K, Kim SW, Zhou C, Su WC, Wang M, Sun Y, Heo DS, Crino L, Tan EH, Chao TY, Shahidi M, Cong XJ,
Lorence RM, Yang JC: Afatinib versus placebo for patients with advanced, metastatic non-small-cell lung cancer after failure of erlotinib, gefitinib, or both, and one or two lines of chemotherapy (LUX-Lung 1): a phase 2b/3 randomised trial. Lancet Oncol 2012, 13(5):528-538.

18. Rini BI, Escudier B, Tomczak P, Kaprin A, Szczylik C, Hutson TE, Michaelson MD, Gorbunova VA, Gore ME, Rusakov IG, Negrier S, Ou YC, Castellano D, Lim HY, Uemura H, Tarazi J, Cella D, Chen C, Rosbrook B, Kim S, Motzer RJ: Comparative effectiveness of axitinib versus sorafenib in advanced renal cell carcinoma (AXIS): a randomised phase 3 trial. Lancet 2011, 378(9807):1931-1939.

19. Cortes JE, Kim DW, Kantarjian HM, Brummendorf TH, Dyagil I, Griskevicius L, Malhotra H, Powell C, Gogat K, Countouriotis AM, Gambacorti-Passerini C: Bosutinib versus imatinib in newly diagnosed chronic-phase chronic myeloid leukemia: results from the BELA trial. J Clin Oncol 2012, 30(28):3486-3492

20. Manning G, Whyte DB, Martinez R, Hunter T, Sudarsanam S: The protein kinase complement of the human genome. Science 2002, 298(5600):1912-1934.

21. Rand V, Huang J, Stockwell T, Ferriera S, Buzko O, Levy S, Busam D, Li K, Edwards JB, Eberhart C, Murphy KM, Tsiamouri A, Beeson K, Simpson AJ, Venter JC, Riggins GJ, Strausberg RL: Sequence survey of receptor tyrosine kinases reveals mutations in glioblastomas. Proc Natl Acad Sci U S A 2005, 102(40):14344-14349.

22. Stupp R, Hegi ME, Mason WP, van den Bent MJ, Taphoorn MJ, Janzer RC, Ludwin SK, Allgeier A, Fisher B, Belanger K, Hau P, Brandes AA, Gijtenbeek J, Marosi C, Vecht CJ, Mokhtari K, Wesseling P, Villa S, Eisenhauer E, Gorlia T, Weller M, Lacombe D, Cairncross JG, Mirimanoff RO, European Organisation for Research and Treatment of Cancer Brain Tumour and Radiation Oncology Groups; National Cancer Institute of Canada Clinical Trials Group: Effects of radiotherapy with concomitant and adjuvant temozolomide versus radiotherapy alone on survival in glioblastoma in a randomised phase III study: 5-year analysis of the EORTC-NCIC trial. Lancet Oncol 2009, 10(5):459-466.

23. Stupp R, Mason WP, van den Bent MJ, Weller M, Fisher B, Taphoorn MJ, Belanger K, Brandes AA, Marosi C, Bogdahn U, Curschmann J, Janzer RC, Ludwin SK, Gorlia T, Allgeier A, Lacombe D, Cairncross JG, Eisenhauer E, Mirimanoff RO, European Organisation for Research and Treatment of Cancer Brain Tumor and Radiotherapy Groups; National Cancer Institute of Canada Clinical Trials Group: Radiotherapy plus concomitant and adjuvant temozolomide for glioblastoma. N Engl J Med 2005, 352(10):987-996.

24. Ohgaki H, Kleihues P: Population-based studies on incidence, survival rates, and genetic alterations in astrocytic and oligodendroglial gliomas. $J$ Neuropathol Exp Neurol 2005, 64(6):479-489.

25. Hegi ME, Rajakannu P, Weller M: Epidermal growth factor receptor: a reemerging target in glioblastoma. Curr Opin Neurol 2012, 25(6):774-779.

26. Beroukhim R, Getz G, Nghiemphu L, Barretina J, Hsueh T, Linhart D, Vivanco I, Lee JC, Huang JH, Alexander S, Du J, Kau T, Thomas RK, Shah K, Soto H, Perner S, Prensner J, Debiasi RM, Demichelis F, Hatton C, Rubin MA, Garraway LA, Nelson SF, Liau L, Mischel PS, Cloughesy TF, Meyerson M, Golub TA, Lander ES, Mellinghoff IK, et al: Assessing the significance of chromosomal aberrations in cancer: methodology and application to glioma. Proc Natl Acad Sci U S A 2007, 104(50):20007-20012.

27. Maher EA, Brennan C, Wen PY, Durso L, Ligon KL, Richardson A, Khatry D, Feng B, Sinha R, Louis DN, Quackenbush J, Black PM, Chin L, DePinho RA: Marked genomic differences characterize primary and secondary glioblastoma subtypes and identify two distinct molecular and clinical secondary glioblastoma entities. Cancer Res 2006, 66(23):11502-11513.

28. Bleeker FE, Molenaar RJ, Leenstra S: Recent advances in the molecular understanding of glioblastoma. J Neurooncol 2012, 108(1):11-27.

29. Mir SE, De Witt Hamer PC, Krawczyk PM, Balaj L, Claes A, Niers JM, Van Tilborg AA, Zwinderman AH, Geerts D, Kaspers GJ, Vandertop WP, Cloos J, Tannous BA, Wesseling P, Aten JA, Noske DP, Van Noorden CJ, Würdinger T: In silico analysis of kinase expression identifies WEE1 as a gatekeeper against mitotic catastrophe in glioblastoma. Cancer Cell 2010, 18(3):244-257.

30. McKusick-Nathans Institute of Genetic Medicine JHUSoM: Online Mendelian Inheritance in Man (OMIM) database. http://www.omim.org/.

31. Institute WTS: Catalogue of Somatic Mutations in Cancer (COSMIC). http:// cancer.sanger.ac.uk/cancergenome/projects/cosmic/.

32. Bleeker FE, Lamba S, Zanon C, van Tilborg AA, Leenstra S, Troost D, Hulsebos T, Vandertop WP, Bardelli A: Absence of AKT1 mutations in glioblastoma. PLoS One 2009, 4(5):e5638. 
33. Bleeker FE, Atai NA, Lamba S, Jonker A, Rijkeboer D, Bosch KS, Tigchelaar W, Troost D, Vandertop WP, Bardelli A, Van Noorden CJ: The prognostic IDH1 ( $\mathrm{R} 132$ ) mutation is associated with reduced NADP + -dependent IDH activity in glioblastoma. Acta Neuropathol 2010, 119(4):487-494.

34. Molenaar RJ, Verbaan D, Lamba S, Zanon C, Jeuken JWM, Boots-Sprenger SHE, Wesseling P, Hulsebos TJM, Troost D, van Tilborg AA, Leenstra S, Vandertop WP, Bardelli A, Van Noorden CJ, Bleeker FE: The combination of IDH1 mutations and MGMT methylation status predicts survival in glioblastoma better than either IDH1 or MGMT alone. Neuro Oncol 2014, 19(9):1263-1267.

35. De Witt Hamer PC, Van Tilborg AA, Eijk PP, Sminia P, Troost D, Van Noorden CJ, Ylstra B, Leenstra S: The genomic profile of human malignant glioma is altered early in primary cell culture and preserved in spheroids. Oncogene 2008, 27(14):2091-2096

36. Gerlach B, Harder AH, Hulsebos TJ, Leenstra S, Slotman BJ, Vandertop WP, Hartmann KA, Sminia P: Radiosensitivity and TP 53, EGFR amplification and LOH10 analysis of primary glioma cell cultures. Strahlenther Onkol 2002, 178(9):491-496.

37. Bielas JH, Loeb KR, Rubin BP, True LD, Loeb LA: Human cancers express a mutator phenotype. Proc Natl Acad Sci U S A 2006, 103(48):18238-18242.

38. Sottoriva A, Spiteri I, Piccirillo SG, Touloumis A, Collins VP, Marioni JC, Curtis C, Watts $C$, Tavare S: Intratumor heterogeneity in human glioblastoma reflects cancer evolutionary dynamics. Proc Natl Acad Sci U S A 2013, 110(10):4009-4014.

39. Loeb LA: Human cancers express mutator phenotypes: origin, consequences and targeting. Nat Rev Cancer 2011, 11(6):450-457.

40. Thomas C, Ely G, James CD, Jenkins R, Kastan M, Jedlicka A, Burger P, Wharen R: Glioblastoma-related gene mutations and over-expression of functional epidermal growth factor receptors in SKMG-3 glioma cells. Acta Neuropathol 2001, 101(6):605-615.

41. Ohgaki $H$, Dessen $P$, Jourde B, Horstmann S, Nishikawa T, Di Patre PL, Burkhard C, Schuler D, Probst-Hensch NM, Maiorka PC, Baeza N, Pisani P, Yonekawa Y, Yasargil MG, Lütolf UM, Kleihues P: Genetic pathways to glioblastoma: a population-based study. Cancer Res 2004, 64(19):6892-6899.

42. Rich JN, Hans C, Jones B, Iversen ES, McLendon RE, Rasheed BK, Dobra A Dressman HK, Bigner DD, Nevins JR, West M: Gene expression profiling and genetic markers in glioblastoma survival. Cancer Res 2005 65(10):4051-4058.

43. Gallia GL, Rand V, Siu IM, Eberhart CG, James CD, Marie SK, Oba-Shinjo SM, Carlotti CG, Caballero OL, Simpson AJ, Brock MV, Massion PP, Carson BS Sr, Riggins GJ: PIK3CA gene mutations in pediatric and adult glioblastoma multiforme. Mol Cancer Res 2006, 4(10):709-714.

44. Yan H, Parsons DW, Jin G, McLendon R, Rasheed BA, Yuan W, Kos I, Batinic-Haberle I, Jones S, Riggins GJ, Friedman H, Friedman A, Reardon D, Herndon J, Kinzler KW, Velculescu VE, Vogelstein B, Bigner DD: IDH1 and IDH2 Mutations in Gliomas. N Engl J Med 2009, 360(8):765-773.

45. Bleeker FE, Lamba S, Leenstra S, Troost D, Hulsebos T, Vandertop WP, Frattini M, Molinari F, Knowles M, Cerrato A, Rodolfo M, Scarpa A, Felicioni L, Buttitta F, Malatesta S, Marchetti A, Bardelli A: IDH1 mutations at residue p.R132 (IDH1(R132)) occur frequently in high-grade gliomas but not in other solid tumors. Hum Mutat 2009, 30(1):7-11.

46. Lee JC, Vivanco I, Beroukhim R, Huang JH, Feng WL, DeBiasi RM, Yoshimoto K, King JC, Nghiemphu P, Yuza Y, Xu Q, Greulich H, Thomas RK, Paez JG, Peck TC, Linhart DJ, Glatt KA, Getz G, Onofrio R, Ziaugra L, Levine RL, Gabriel S, Kawaguchi T, O'Neill K, Khan H, Liau LM, Nelson SF, Rao PN, Mischel P, Pieper RO, et al: Epidermal growth factor receptor activation in glioblastoma through novel missense mutations in the extracellular domain. PLoS Med 2006, 3(12):e485.

47. Brennan CW, Verhaak RG, McKenna A, Campos B, Noushmehr H, Salama SR, Zheng S, Chakravarty D, Sanborn JZ, Berman SH, Beroukhim R, Bernard B, Wu CJ, Genovese G, Shmulevich I, Barnholtz-Sloan J, Zou L, Vegesna R, Shukla SA, Ciriello G, Yung WK, Zhang W, Sougnez C, Mikkelsen T, Aldape K, Bigner DD, Van Meir EG, Prados M, Sloan A, Black KL, et al: The somatic genomic landscape of glioblastoma. Cell 2013, 155(2):462-477.

48. Wood LD, Parsons DW, Jones S, Lin J, Sjoblom T, Leary RJ, Shen D, Boca SM, Barber T, Ptak J, Silliman N, Szabo S, Dezso Z, Ustyanksky V, Nikolskaya T, Nikolsky Y, Karchin R, Wilson PA, Kaminker JS, Zhang Z, Croshaw R, Willis J, Dawson D, Shipitsin M, Willson JK, Sukumar S, Polyak K, Park BH, Pethiyagoda CL, Pant PV, et al: The genomic landscapes of human breast and colorectal cancers. Science 2007, 318(5853):1108-1113.

49. Lynch TJ, Bell DW, Sordella R, Gurubhagavatula S, Okimoto RA, Brannigan BW, Harris PL, Haserlat SM, Supko JG, Haluska FG, Louis DN, Christiani DC
Settleman J, Haber DA: Activating mutations in the epidermal growth factor receptor underlying responsiveness of non-small-cell lung cancer to gefitinib. N Engl J Med 2004, 350(21):2129-2139.

50. Stephens P, Hunter C, Bignell G, Edkins S, Davies H, Teague J, Stevens C, O'Meara S, Smith R, Parker A, Barthorpe A, Blow M, Brackenbury L, Butler A, Clarke O, Cole J, Dicks E, Dike A, Drozd A, Edwards K, Forbes S, Foster R, Gray K, Greenman C, Halliday K, Hills K, Kosmidou V, Lugg R, Menzies A, Perry J, et al: Lung cancer: intragenic ERBB2 kinase mutations in tumours. Nature 2004, 431(7008):525-526.

51. Day BW, Stringer BW, Al-Ejeh F, Ting MJ, Wilson J, Ensbey KS, Jamieson PR, Bruce ZC, Lim YC, Offenhauser C, Charmsaz S, Cooper LT, Ellacott JK, Harding A, Leveque L, Inglis P, Allan S, Walker DG, Lackmann M, Osborne G, Khanna KK, Reynolds BA, Lickliter JD, Boyd AW: EphA3 maintains tumorigenicity and is a therapeutic target in glioblastoma multiforme. Cancer Cell 2013, 23(2):238-248.

52. Rohle D, Popovici-Muller J, Palaskas N, Turcan S, Grommes C, Campos C, Tsoi J, Clark O, Oldrini B, Komisopoulou E, Kunii K, Pedraza A, Schalm S, Silverman L, Miller A, Wang F, Yang H, Chen Y, Kernytsky A, Rosenblum MK, Liu W, Biller SA, Su SM, Brennan CW, Chan TA, Graeber TG, Yen KE, Mellinghoff IK: An inhibitor of mutant IDH1 delays growth and promotes differentiation of glioma cells. Science 2013, 340(6132):626-630.

53. Jin G, Reitman ZJ, Duncan CG, Spasojevic I, Gooden DM, Rasheed BA, Yang R, Lopez GY, He Y, McLendon RE, Bigner DD, Yan H: Disruption of wild-type IDH1 suppresses D-2-hydroxyglutarate production in IDH1-mutated gliomas. Cancer Res 2013, 73(2):496-501.

54. Luchman HA, Stechishin OD, Dang NH, Blough MD, Chesnelong C, Kelly JJ, Nguyen SA, Chan JA, Weljie AM, Cairncross JG, Weiss S: An in vivo patient-derived model of endogenous IDH1-mutant glioma. Neuro Oncol 2012, 14(2):184-191.

55. Luchman HA, Chesnelong C, Cairncross JG, Weiss S: Spontaneous loss of heterozygosity leading to homozygous $\mathrm{R} 132 \mathrm{H}$ in a patient-derived IDH1 mutant cell line. Neuro Oncol 2013, 15(8):979-980.

56. Li A, Walling J, Kotliarov Y, Center A, Steed ME, Ahn SJ, Rosenblum M, Mikkelsen T, Zenklusen JC, Fine HA: Genomic changes and gene expression profiles reveal that established glioma cell lines are poorly representative of primary human gliomas. Mol Cancer Res 2008, 6(1):21-30.

57. Balakrishnan A, Bleeker FE, Lamba S, Rodolfo M, Daniotti M, Scarpa A, van Tilborg AA, Leenstra S, Zanon C, Bardelli A: Novel somatic and germline mutations in cancer candidate genes in glioblastoma, melanoma, and pancreatic carcinoma. Cancer Res 2007, 67(8):3545-3550.

58. Kita D, Yonekawa $Y$, Weller M, Ohgaki H: PIK3CA alterations in primary (de novo) and secondary glioblastomas. Acta Neuropathol 2007, 113(3):295-302.

59. Broderick DK, Di C, Parrett TJ, Samuels YR, Cummins JM, McLendon RE, Fults DW, Velculescu VE, Bigner DD, Yan H: Mutations of PIK3CA in anaplastic oligodendrogliomas, high-grade astrocytomas, and medulloblastomas. Cancer Res 2004, 64(15):5048-5050.

60. Frattini M, Signoroni S, Pilotti S, Bertario L, Benvenuti S, Zanon C, Bardelli A, Pierotti MA: Phosphatase protein homologue to tensin expression and phosphatidylinositol-3 phosphate kinase mutations in colorectal cancer. Cancer Res 2005, 65(23):11227.

61. Saal LH, Holm K, Maurer M, Memeo L, Su T, Wang X, Yu JS, Malmstrom PO, Mansukhani M, Enoksson J, Hibshoosh H, Borg A, Parsons R: PIK3CA mutations correlate with hormone receptors, node metastasis, and ERBB2, and are mutually exclusive with PTEN loss in human breast carcinoma. Cancer Res 2005, 65(7):2554-2559.

62. Cantley LC: The phosphoinositide 3-kinase pathway. Science 2002, 296(5573):1655-1657.

63. Brugge J, Hung MC, Mills GB: A new mutational AKTivation in the PI3K pathway. Cancer Cell 2007, 12(2):104-107.

64. Grzmil M, Hemmings BA: Overcoming resistance to rapalogs in gliomas by combinatory therapies. Biochim Biophys Acta 2013, 1834(7):1371-1380.

65. Sami A, Karsy M: Targeting the PI3K/AKT/mTOR signaling pathway in glioblastoma: novel therapeutic agents and advances in understanding. Tumour Biol 2013, 34(4):1991-2002.

66. Wick W, Puduvalli VK, Chamberlain MC, van den Bent MJ, Carpentier AF, Cher LM, Mason W, Weller M, Hong S, Musib L, Liepa AM, Thornton DE, Fine HA: Phase III study of enzastaurin compared with lomustine in the treatment of recurrent intracranial glioblastoma. J Clin Oncol 2010, 28(7):1168-1174.

67. Brown PD, Krishnan S, Sarkaria JN, Wu W, Jaeckle KA, Uhm JH, Geoffroy FJ, Arusell R, Kitange G, Jenkins RB, Kugler JW, Morton RF, Rowland KM Jr, 
Mischel P, Yong WH, Scheithauer BW, Schiff D, Giannini C, Buckner JC, North Central Cancer Treatment Group Study N0177: Phase I/II trial of erlotinib and temozolomide with radiation therapy in the treatment of newly diagnosed glioblastoma multiforme: North Central Cancer Treatment Group Study N0177. J Clin Oncol 2008, 26(34):5603-5609.

68. Haas-Kogan DA, Prados MD, Tihan T, Eberhard DA, Jelluma N, Arvold ND, Baumber R, Lamborn KR, Kapadia A, Malec M, Berger MS, Stokoe D: Epidermal growth factor receptor, protein kinase $\mathrm{B} / \mathrm{Akt}$, and glioma response to erlotinib. J Natl Cancer Inst 2005, 97(12):880-887.

69. Yung WK, Vredenburgh JJ, Cloughesy TF, Nghiemphu P, Klencke B, Gilbert MR, Reardon DA, Prados MD: Safety and efficacy of erlotinib in first-relapse glioblastoma: a phase II open-label study. Neuro Oncol 2010, 12(10):1061-1070

70. Mellinghoff IK, Wang MY, Vivanco I, Haas-Kogan DA, Zhu S, Dia EQ, Lu KV, Yoshimoto K, Huang JH, Chute DJ, Riggs BL, Horvath S, Liau LM, Cavenee WK, Rao PN, Beroukhim R, Peck TC, Lee JC, Sellers WR, Stokoe D, Prados M, Cloughesy TF, Sawyers CL, Mischel PS: Molecular determinants of the response of glioblastomas to EGFR kinase inhibitors. N Engl J Med 2005, 353(19):2012-2024.

71. van den Bent MJ, Brandes AA, Rampling R, Kouwenhoven MC, Kros JM, Carpentier AF, Clement PM, Frenay M, Campone M, Baurain JF, Armand JP, Taphoorn MJ, Tosoni A, Kletzl H, Klughammer B, Lacombe D, Gorlia T: Randomized phase II trial of erlotinib versus temozolomide or carmustine in recurrent glioblastoma: EORTC brain tumor group study 26034. J Clin Oncology 2009, 27(8):1268-1274.

72. Reardon DA, Desjardins A, Vredenburgh JJ, Gururangan S, Friedman AH, Herndon JE 2nd, Marcello J, Norfleet JA, McLendon RE, Sampson JH, Friedman HS: Phase 2 trial of erlotinib plus sirolimus in adults with recurrent glioblastoma. J Neurooncol 2010, 96(2):219-230.

73. Ciriello G, Miller ML, Aksoy BA, Senbabaoglu Y, Schultz N, Sander C: Emerging landscape of oncogenic signatures across human cancers. Nat Genet 2013, 45(10):1127-1133.

74. Zack TI, Schumacher SE, Carter SL, Cherniack AD, Saksena G, Tabak B, Lawrence MS, Zhang CZ, Wala J, Mermel CH, Sougnez C, Gabriel SB, Hernandez B, Shen H, Laird PW, Getz G, Meyerson M, Beroukhim R: Pan-cancer patterns of somatic copy number alteration. Nat Genet 2013, 45(10):1134-1140

75. Roth AD, Tejpar S, Delorenzi M, Yan P, Fiocca R, Klingbiel D, Dietrich D, Biesmans B, Bodoky G, Barone C, Aranda E, Nordlinger B, Cisar L, Labianca R, Cunningham D, Van Cutsem E, Bosman F: Prognostic role of KRAS and BRAF in stage II and III resected colon cancer: results of the translational study on the PETACC-3, EORTC 40993, SAKK 60-00 trial. J Clin Oncol 2010, 28(3):466-474.

76. Prahallad A, Sun C, Huang S, Di Nicolantonio F, Salazar R, Zecchin D, Beijersbergen RL, Bardelli A, Bernards R: Unresponsiveness of colon cancer to BRAF(V600E) inhibition through feedback activation of EGFR. Nature 2012, 483(7387):100-103.

77. De Witt Hamer PC, Mir SE, Noske D, Van Noorden CJ, Wurdinger T: WEE1 kinase targeting combined with DNA-damaging cancer therapy catalyzes mitotic catastrophe. Clin Cancer Res 2011, 17(13):4200-4207.

78. Gravendeel LA, Kouwenhoven MC, Gevaert O, de Rooi JJ, Stubbs AP, Duijm JE, Daemen A, Bleeker FE, Bralten LB, Kloosterhof NK, De Moor B, Eilers PH, van der Spek PJ, Kros JM, Sillevis Smitt PA, van den Bent MJ, French PJ: Intrinsic gene expression profiles of gliomas are a better predictor of survival than histology. Cancer Res 2009, 69(23):9065-9072.

79. Phillips HS, Kharbanda S, Chen R, Forrest WF, Soriano RH, Wu TD, Misra A, Nigro JM, Colman H, Soroceanu L, Williams PM, Modrusan Z, Feuerstein BG, Aldape K: Molecular subclasses of high-grade glioma predict prognosis, delineate a pattern of disease progression, and resemble stages in neurogenesis. Cancer Cell 2006, 9(3):157-173.

80. Verhaak RG, Hoadley KA, Purdom E, Wang V, Qi Y, Wilkerson MD, Miller CR, Ding L, Golub T, Mesirov JP, Alexe G, Lawrence M, O'Kelly M, Tamayo P, Weir BA, Gabriel S, Winckler W, Gupta S, Jakkula L, Feiler HS, Hodgson JG, James CD, Sarkaria JN, Brennan C, Kahn A, Spellman PT, Wilson RK, Speed TP, Gray JW, Meyerson M, Getz G, Perou CM, Hayes DN: Integrated genomic analysis identifies clinically relevant subtypes of glioblastoma characterized by abnormalities in PDGFRA, IDH1, EGFR, and NF1. Cancer Cell 2010, 17(1):98-110.

81. Vogelstein B, Papadopoulos N, Velculescu VE, Zhou S, Diaz LA Jr, Kinzler KW: Cancer genome landscapes. Science 2013, 339(6127):1546-1558.
82. Molenaar RJ, Radivoyevitch T, Maciejewski JP, van Noorden CJ, Bleeker FE: The driver and passenger effects of isocitrate dehydrogenase 1 and 2 mutations in oncogenesis and survival prolongation. Biochim Biophys Acta 2014, 1846(2):326-341.

83. Thompson CB: Metabolic enzymes as oncogenes or tumor suppressors. N Engl J Med 2009, 360(8):813-815.

84. van Lith SA, Navis AC, Verrijp K, Niclou SP, Bjerkvig R, Wesseling P, Tops B, Molenaar R, van Noorden CJ, Leenders WP: Glutamate as chemotactic fuel for diffuse glioma cells: Are they glutamate suckers? Biochim Biophys Acta 2014, 1846(1):66-74.

85. Lawrence MS, Stojanov P, Mermel CH, Robinson JT, Garraway LA, Golub TR, Meyerson M, Gabriel SB, Lander ES, Getz G: Discovery and saturation analysis of cancer genes across 21 tumour types. Nature 2014, 505(7484):495-501.

doi:10.1186/1471-2407-14-718

Cite this article as: Bleeker et al:: Mutational profiling of kinases in glioblastoma. BMC Cancer 2014 14:718.

\section{Submit your next manuscript to BioMed Central and take full advantage of:}

- Convenient online submission

- Thorough peer review

- No space constraints or color figure charges

- Immediate publication on acceptance

- Inclusion in PubMed, CAS, Scopus and Google Scholar

- Research which is freely available for redistribution

Submit your manuscript at www.biomedcentral.com/submit
C Biomed Central 